\title{
A Study on the Core Values of the Brand
}

\author{
Xiangyin Li, Cui Sun \\ School of Management, Jinan University, Guangzhou, China \\ Email: suntus1991@126.com
}

Received 25 November 2015; accepted 20 December 2015; published 23 December 2015

Copyright (C) 2015 by authors and Scientific Research Publishing Inc.

This work is licensed under the Creative Commons Attribution International License (CC BY). http://creativecommons.org/licenses/by/4.0/

(c) (†) Open Access

\begin{abstract}
Product homogenization becomes serious today; how to use the brand core values to seek differentiated competitive advantage has become the key to brand strategy. Based on the domestic and international studies, this paper summarizes the connotation of the brand core values, the dimensions and measure of the brand core values, and the relationships between the brand core values and other marketing variables, trying to show the overall framework of the brand core values research. Meanwhile, it points out the shortcomings of existing research and research prospects for the future, so as to provide reference for future research.
\end{abstract}

\section{Keywords}

\section{Brand Core Values, Review, Prospect}

\section{Introduction}

With the continuous development of social progress and mature market, the variety of goods is increasingly diverse; market competition has shifted to brand competition by the advertising and marketing competition. Consumers choose between different brands in order to maximize personal utility, mainly by comparing their need structure and the value which constitute branded products, because the brand also provides consumers to express themselves, and pursue ways of emotional satisfaction besides the product itself. Consumers obtain the added value on the product through the consumption of the brand products, to achieve the brand core values of shift from products to consumers, so that the core values of the brand will affect consumers' purchasing decisions [1].

One of the ultimate goals of corporate marketing is to establish a strong relationship bond between consumers and brands, and the core value of brand is the basis for the establishment of the relationship between consumers and the brand, a direct impact on the success of the brand. Today, however, most enterprises in China have not set up the correct view of the brand, and almost have no accurate positioning of the brand values. Brand core value is not clear; lack of personality, and brand character tends to be similar. The result has been a succession of advertising campaigns and price war. Thus, shaping the brand core values has become imperative. In recent years, the academy has conducted more research on core values of the brand, but foreign scholars mainly studied 
from the customer's point of view rather than the brand value, and domestic scholars conducted less empirical research. Therefore, it is necessary to research brand core values. This article focuses on the core brand values to sort out related research, in order to provide guidance or reference for corporate brand building. Throughout the existing research, the core values of brand mainly include: What are the core values of the brand? What is included? What is the relationship between the core values of the brand and brand loyalty, brand extension and other variables?

\section{Concept and Connotation of the Brand Core Values}

Before being widely accepted, western scholars have used "brand essence", "brand mantra", "Brand code", "brand themes" and other words to represent the core values of the brand. Aaker thinks "brand essence" is a part of the brand identity, it has all core brand identity; Upshaw thinks the "brand essence" is the intrinsic value of the brand, is the core of the core brands; Helena thinks that "brand code" defines the uniqueness of the brand, is the source of brand power; Randazzo thinks "brand themes" is the symbol of the brand, is the spiritual center, which determines the characteristics of the brand and is reflected in all aspects of the brand. Until 1997 Walker Chip used the "brand core values" of the concept in "The perils of popularity" in an article for the first time, and pointed out that it is the core interest of the brand promise to consumers, and represents the ultimate significance and unique value to consumers, is a unique and most valuable brand essence [2]. Meanwhile, Walker Chip also pointed out that the core values of the brand should be brand-oriented rather than product-oriented, in order to maintain its leading position of the brand, companies must establish a lasting relationship with the customer in the brand core values, because the core values of the brand provides a reason to select the brand to consumers. Since then, research-related aspects of the brand core values began to receive more attention. Western scholar Mats [3] analyzes the relationships between the core brand values, enterprise value and brand value-added; Keller [4] considers the core brand values is a series of relationships between brand association and brand value-added, which can reflect the most unique 5 - 10 aspects of the brand.

In the domestic research, our brand strategy and marketing, advertising scholar Weng Xiangdong [5] argues, the core values of the brand is the main part of brand equity, it allows consumers to clearly identify and remember the brand personality point of interest, and even dominantly force the consumers to fall in love with a brand. Bai Xueyan [6] believes that the core values of the brand is the brand concept, is an important symbol in the test of a strong degree of brand. Wang $\mathrm{Xu}$ [7] defines the core values of the brand as: the ability to provide high value to consumers while excess profits for the enterprise, decides consumers whether to purchase the brand merchandise to a certain extent. Luo Jiujiu [8] points out that the brand core values offers consumers unique interests and values which are different from other brands, also it is a concentrated expression of a brand personality and culture. Chen Dong [9] considers the brand core values is the ultimate pursuit of rationality and the corresponding demand from its own brand identity and brand objectives. Yao Jie [10] suggests that brand core values is the soul and essence of the brand, is the brand's promise to consumers and throughout the whole process of brand development.

From the above definition of the core values of the brand, although there are differences in views of these scholars, but the brand core values is generally considered to be different from other brands and offers unique benefits and value to consumers, is the soul of the brand, is the performance of enterprise competitiveness, and also is the inner spirit when build a brand.

\section{Dimensions of the Brand Core Values}

The dimensions of the brand core values constitute the most telling connotation of the brand's core values; according to the amount of the core values of the brand contained dimensions, we may divide the brand core values into two-dimensional, three-dimensional and multidimensional.

\subsection{Two-Dimensional}

Chernatony and Mcdonald believe that the brand concept is characterized by the presentation of two metrics, one is rational function, and the other is a symbol of emotional. Zhang Xiaoyan [11] also believes that the brand core values includes the emotional value and rational value into two parts, in which the emotional values include historical heritage, personality characteristics, social characteristics, personal contact degree and perceived value, rational values include perceived quality and functional benefits. 


\subsection{Three-Dimensional}

Most scholars agree that the brand core values is three-dimensional, but the specific meaning of the threedimensional content is also different. For example, Park, Jaworski and Maclnnis believe that the brand offers three kinds of benefits to consumers, namely functional benefits, symbolic interests and experiential interests. Among them, the functional benefits can be allocated to the value of a property related to the product type (functional or rational), the latter two can be classified as non-product value (mental or emotional). Sun Zaiguo [12] advices that when you want to plan and refine the core values of the brand, you can choose from the following aspects: functional value, mental or emotional value, self-expression values. Wang Yanchen deconstructs the core values of the brand into three dimensions: the physical dimension, the emotional dimension and the symbolic value dimensions. Physical dimension is the most basic dimension of core values of the brand; affective dimension is to construct a life style, culture, spiritual world, and guide consumers to obtain sustenance and emotional resonance in commodity consumption through the emotional attachment of goods or dependent effect.

\subsection{Multidimensional}

Wang Yan [13] points out that the essence of core values of the brand locates the core values of the brand from the following four aspects: brand attributes, brand benefit, brand value and brand personality. Luo Jiujiu and Wu Qingsheng point out that the establishment of the core brand values, not just should be based on consumer demand, but also should be to compare the advantages and disadvantages of competing brands, at the same time it should reflect the corporate mission and vision, which consists of four dimensions constitute, respectively it is the physical dimension, emotional dimension, symbolic value dimension and enterprise value dimensions. Physical dimension mainly refers to the utility and value of the products, emotional dimension of the product impresses consumers from the heart deeply, so that consumers of the brand will form an emotional sustenance or emotional dependence, symbolic value dimension could be one set of values, attitudes or certain characteristics to form a specific image of flesh and blood, to win consumer recognition. In addition, an important source of brand core values is the core values of the corporate, corporate mission answers the question "Who am I", which is based on the enterprises to carry out various business activities, is the starting point of corporate brand building and driving force, which includes the interests of requirements and corporate social responsibility. Corporate vision answers the question "Where am I going", which determines the direction of enterprise development, and core values of enterprises is spiritual core in pursuit of the vision and mission, is the views and attitudes towards enterprise customers, employees, competitors, society, etc.

There are also different views that brand core values constitute six elements and eight elements. Six elements say that the corporate brand connotation, namely the brand core values should include specific product attributes, functional and emotional benefits, and a sense of enterprise value, brand culture, brand personality and target consumers [14]. Eight elements hold the view that personality factors, conformity, culture, symbol, mission, trust, habits and consistency are the eight areas which constitute the core values of the brand [15]. Six boundaries are not so clear, or there is an overlap, eight elements put its core brand values reflect the functional characteristics without distinction to be listed, resulting in difficult to understand [16].

Although there are different views about the dimensions of brand core values, however, the current situation is that most scholars believe that the core values of the brand is a three dimensional concept.

\section{The Relationship between the Brand Core Values and Other Variables}

In the empirical research related to the core values of the brand, many scholars have explored the core values of the brand and brand loyalty, brand extension and other relations between the variables, the brand core values is introduced as the variables of different types in research.

\subsection{The Brand Core Values as the Independent Variables}

Brand core values can build and maintain brand loyalty [17]. In terms of the relationship between the different types of brand value and brand loyalty, Yu Chunling [18] concludes that functional value, symbolic value and the value of the experience have regional differences in driving brand loyalty effect through empirical study. Wu Peng et al. considers brand core values with a high level gives additional value of social and psychological level beyond product functionality, it guarantees to achieve high brand loyalty. Zhang Qiongfang has indicated that 
functional value of shopping sites, customer brand experience, the relationship experience have a significant role to enhance loyalty through empirical studies. Lu Songfu proposes brand loyalty is built on the brand perceived quality, brand experience, brand emotion, and brand reputation, thus functional value and emotional value of the brand can bring brand loyalty. About the relationship between affective value and brand loyalty, scholars have also conducted more research. Thomson et al. [19] have verified the three basic dimensions of brand emotional attachment scale, "love", "passion" and "link", have excellent predictive validity on brand loyalty and willingness to pay a premium. Zhou Linsen et al. [20] propose the creation of the emotional value can improve customer loyalty in the context of analysis of constitute factors of the brand emotional value. Symbolic value also plays an important role for the brand loyalty, Yao Shanji says that consumers buy the brand in order to have status, values, identity, then the brand's core values play a major role, it's easy to form brand loyalty.

In addition, some scholars study the relationship between the brand core values and brand extension. Wang $\mathrm{Xu}$ presents the brand core values is the center of decision-making of brand extension, decides the brand covers and brand extension force, besides the success of the brand extension in turn further strengthen and enhance the existing connotation of the brand core values. Chen Zhuohao et al. [21] empirically reveals the brand personality matching has a significant impact on consumer brand extension evaluation through experimental studies and confirmatory factor analysis based on perceptual matching connotation. Domestic research on brand personality also believes that the brand personality plays an important role in formation of corporate branding and consumer brand attitudes. The results from the data support the brand personality match has a positive impact on brand extension evaluation (including the brand extension attitude and willingness to buy the product), and also demonstrates brand personality match has a more significant impact than matching category. Wang Yanchen analyzes on the relationship between the dimensions of the core values of the brand and brand extension, it demonstrates the emotional dimension and symbolic dimensions of brand value determine the success of brand extension and cross-border capabilities.

It can be seen that studying the impact of core values of the brand to other marketing variables further validates the importance of brand core values on brand building when we think of the brand core values as the independent variable. These results provide a guideline and basis for the Chinese brand building and brand extension. If our brand can consciously proceed from the point of view of the brand core values to actively build consumer brand relationships, establish contact with consumers emotionally, then consumers are likely to form a relatively high brand loyalty, and also easier to accept brand extensions.

\subsection{The Brand Core Values as the Dependent Variable}

It has been mainly studied the core brand values as the independent variables, the brand core values as the dependent variable, analysis of the pre-variable effects on the brand core values is very few. Yao Jie studies on the shaping the brand core values to brand loyalty-oriented, the empirical results show that product quality, functional innovation and customer response play a significant role to the brand functional values, communication, humaneness and integrity have significant role in promoting brand emotional values, self-expression and social prestige have significant role in promoting brand symbolic values. Studying which variables have a positive or negative impact on the brand core values is more operational for enterprises brand building when we regard the brand core values as the dependent variable. Currently similar studies are relatively small, but such studies are more meaningful for the brand core values practical application, so it is one of the areas of future research could expand.

\subsection{The Brand Core Values as Mediator or Moderator}

In existing empirical research, there are some scholars examine the relationship between other variables while put the brand core values as mediating variables or manipulated variables. For example, Gong Yanping et al. [22] use structural equation modeling to verify the brand trust and the brand symbolic values play mediating effect on the influence of brand extension to consumer brand loyalty. Joining the brand core values as mediator or moderator into relevant studies to explore the mechanism of influence of other variables, to some extent, can verify the role of the brand core values to other variables on the other hand, and enrich the research.

\section{Research Prospects}

This paper summarizes the research of the brand core values theory, in order to provide researchers with an 
overall understanding of the theory about the core values of the brand. Meanwhile, studies have found combing through the limitations of existing research, it is recommended to carry out in-depth studies in the future from the following two aspects:

First, study on the antecedents of the core values of the brand. From a practical application point of view, companies pay more attention to the practical operation which factors or variables affect the core values of the brand. At present, more and more enterprises have begun to realize the importance of brand building, but could not know how to start. Such studies focus on factors affecting the formation of the core values of the brand, to clearly inform what variables have a direct impact on the formation of the brand core values, and provide direct evidence for the business practice.

Second, unify the dimensions of the brand core values for the entire study. We find that in empirical researches, when it comes to the relationships between the brand core values and other variables, most are analyzed from a particular dimension of the core brand values separately, few regard core values of the brand as a whole empirical study. Core brand values is a complete concept, comparing every dimension of the brand core value affecting other variables is a worthy research direction.

\section{Conclusion}

Only a brand has a clear core value, it can provide a clear specification and guidance for enterprises to build a strong brand, communicate this value to the consumer with an appropriate way, thus further enhance consumer's brand awareness and loyalty, and accumulate brand values. Many enterprises have realized the important role of the core values of the brand, but what the enterprises really need to resolve is that how to shape the brand core values. If enterprises want to build core values of the brand, they must first clear the influence factors of the brand core values. Follow-up studies can help enterprises build the brand core values specifically through the study of the factors influencing the core values of the brand, and can focus on the different dimensions' role of the brand core values to other variables.

\section{References}

[1] Wang, Y.C. and Jiao, Y. (2010) The Analysis of Brand Core Value Dimensions and Brand Extension. Business Times, 4, 33.

[2] Chip, W. (1997) The Perils of Popularity. Marketing Tools, 7, 21-22.

[3] Urde, M. (2003) Core Value Based Corporate Brand Building. European Journal of Marketing, 7, 1017-1040.

[4] Keller, K.L. (2003) Brand Synthesis the Multidim Ensionality of Brand Knowledge. Journal of Consumer Research, 29, 595-600. http://dx.doi.org/10.1086/346254

[5] Weng, X.D. (2002) Local Brand Strategy. Zhejiang People’s Publishing House, Hangzhou.

[6] Bai, X.Y. and Fu, L. (2005) Promotion and Application of the Brand Core Values. Business Research, 332, 69-70.

[7] Wang, X. (2006) Analysis the Relationship of the Core Values of the Brand and Brand Extension and Inspiration. Market Modernization, 487, 57-59.

[8] Luo, J.J. (2007) The Core Values of the Brand and Its Four-Dimensional Model-Real Estate “Olympic Park” as an Example. Anhui Agricultural Sciences, 7, 2192-2194.

[9] Chen, D. and Wei, P. (2011) Study on the Brand Core Values. Technological Economy, 30, 108-116.

[10] Yao, J. (2011) Study on the Brand Core Values-Oriented Brand Loyalty. Jinan University, Guangzhou.

[11] Zhang, X.Y. (2011) Analysis on the Realization of the Core Values of the Brand. Medium and Small Business Management and Technology, 7, 9-10.

[12] Sun, Z.G. (2005) Shape the Brand Core Values. Business Times, 17, 44-45, 49.

[13] Wang, Y. (2004) Study on the Brand Core Values. Jilin University, Changchun.

[14] Chen, H.Y. (2007) Study on Enterprise Brand. China Economic Publishing House, Beijing.

[15] Shi, G.Q. (2008) Into the Depths of the Brand-To Explore the Brand Core Values. China Township Enterprises, 6, 28-29.

[16] Tan, Y. (2010) Analysis on the Theoretical Foundation of Brand Core Values. Economic Research Guide, 27, $178-179$.

[17] Zhou, W.J. (2006) Domestic Shampoo Brand Core Values Study in Guangdong Province. Jinan University, Guangzhou. 
[18] Yu, C.L., Wang, H.Z., Zhao, P. and Lin, R. (2005) Regional Differences in the Drivers of Brand Loyalty Analysis. China Industrial Economy, 12, 115-121.

[19] Thomson, M., Maclnnis, D.J. and Park, C.W. (2005) The Ties That Bind: Measuring the Strength of Consumers’ Emotional Attachments to Brands. Journal of Consumer Psychology, 15, 77-91. http://dx.doi.org/10.1207/s15327663jcp1501_10

[20] Zhou, L.S. and Zhang, L. (2004) On the Creation of Brand Emotional Values. Business Research, 298, 140-143.

[21] Chen, Z.H. and Lu, Z. (2008) Study on the Impact of Brand Personality Match to Brand Extension-Based on Analysis of the Connotation of Perception Match. China Industrial Economy, 247, 85-95.

[22] Gong, Y.P. and Fan, S.L. (2008) Study on the Influence of Brand Extension to Consumer Brand Loyalty-An Empirical Study Based on Brand Trust and Brand Symbolic Values. Soft Science, 99, 63-68. 